\title{
Serum Cortisol Levels Modifications in Patients with Depression and Irritable Bowel Syndrome
}

\author{
LUMINITA DIANA HRITCU1', MANUELA PADURARIU2, ALIN CIOBICA ${ }^{3,4,5}$, CRISTINA HORHOGEA ${ }^{2 *}$, MIHAELA CLAUDIA SPATARU ${ }^{1}$, \\ CONSTANTIN SPATARU ${ }^{1}$, LIVIU BURTAN ${ }^{1 *}$, CRISTINEL STEFANESCU ${ }^{2}$ \\ ${ }^{1}$ Ion Ionescu de la Brad University of Agricultural Science and Veterinary Medicine, 3 Sadoveanu Alley, 700490, Iasi Romania \\ ${ }^{2}$ Grigore T.Popa University of Medicine and Pharmacy, 16, Universitatii Str., 700115, Iasi, Romania \\ ${ }^{3}$ Alexandru Ioan Cuza University, Department of Research, Faculty of Biology, 11 Carol I Blvd., 700506, lasi, Romania \\ ${ }^{4}$ Academy of Romanian Scientists, 54 Splaiul Independentei, 050094, Bucharest, Romania \\ ${ }^{5}$ Center of Biomedical Research, Romanian Academy, Iasi, 8 Carol I Blvd., 700506, Romania
}

\begin{abstract}
The correlations between depression and stress are quite accepted nowadays, as well as the fact that cortisol levels could also represent fundamental risk factors for major depressive disorder. However, when itcomes to the modifications of cortisol levels in depression, the results are controversial. Same goes for the cortisol modifications in irritable bowel syndrome (IBS), which is a functional digestive disorder characterized by a strong biopsychological component, being highly influenced or exacerbated by stressful stimuli. Thus, in the present report we were interested in seeing if there are any serum cortisol levels variations in patients with depression and irritable bowel syndrome, by looking at cortisol modifications in two different groups of patients: a control group with major depression disorder and another study group composed by major depression disorder + IBS patients. Thus, our data presented here are suggesting that there is a significant increase in cortisol levels in the morning serum of the patients with major depression disorder + IBS, aS compared to the group having only depression. The results presented here could have an importantrelevance in the context of managing the stress-related factors in the pathological entities described above.
\end{abstract}

Keywords: cortisol, serum, depression, irritable bowel syndrome

The correlations between depression and stress are well known and studied (e.g. a specific stress factor could represent a risk factor for depression) [1,2]. Lately there is also generally accepted that a dysbalance in the hypothalamic-pituitary-adrenal (HPA) axis (ex. excessive stimulation of this axis) and the cortisol levels could also represent fundamental risk factors for major depressive disorder [3].

However, when it comes to the modifications of cortisol levels in depression, the results are very controversial with previous reports describing: increased levels in al most half of depressed patients [4], especially in the morning [5, 6], as cited in [7], decreased levels in depression, for example after very traumatic events [8], in less severely depressed population or non-melancholic or non-psychotic depression [9-12], as cited in [7]; while other authors described circadian variations and pulsatile secretions modifications in this way, as for example increased levels in the morning and reduced concentrations during the day [ 7] or even large studies showing increased levels of cortisol in major depressive disorder (MDD) both in the morning and in the evening [13], as cited in [7].

Also, there is an important correlation between oxytocin, HPA axis and cortisol levels in the depressive pathophysiology, as our group previously demonstrated [14].

On the other side, irritable bowel syndrome (IBS) is a functional digestive disorder characterized by stool abnormalities, diarrhea, constipation or both form alternating between them over time, accompanied by abdominal pain, bloating or flatulence, withoutanatomical/ structural deficits [15]. Even more importantly, this disorder is considered lately a biopsychological clinical entity which is highly influenced and could be exacerbated by stressful stimuli $[16,17]$, being associated with a variety of neuropsychiatric manifestations $[15,18,19]$.
In this way, there are also various results in the context of cortisol modifications in IBS (e.g. increased levels of cortisol in IBS [20-22], as cited in [16] vs. no modifications of cortisol levels in IBS patients [22-26], as cited in [16]), with the Patacchioli group demonstrating in 2001 [17] for example that IBS subjects showed significantly increased levels of salivary cortisol in their saliva in the morning, and exhibiting decreased levels of cortisol in the evening [17], while Sugaya et al. [16], reported a significant increase of salivary cortisol levels in individuals with IBS only in the first week of the experimental prolonged stressful exposure, but not in the second week of the expose or a few days after [16].

Thus, in the present report we were interested in seeing for the first time in our best of knowledge if there are any serum cortisol levels variations in patients with depression and irritable bowel syndrome, by looking at cortisol modifications in two different groups of patients: a control group with major depression disorder and another study group composed by major depression disorder + IBS patients.

\section{Experimental part}

Material and methods

In the present study, we selected patients that were admitted in Socola Psychiatric Hospital with the diagnostic of depression and irritable bowel syndrome. The patients signed an informed consent and were screened to be included in our study and local committee approved the study. Patients with other major psychiatric disorder, patients suffering from other digestive illnesses, with other untreated somatic diseases were excluded from the study.

The diagnostic of depression was established following ICD-10 and DSM V criteria and the diagnostic of irritable bowel syndrome met the ROME IV criteria. The patients (total $n=12$ ) were psychometric tested with HAMD scale.

\footnotetext{
* email: rebegeacristina@yahoo.com; burtan_liviu@yahoo.com
} 
A control group was selected that included patients with depression without digestive symptoms $(n=8)$. We collected blood samples from all the patients to test the cortisol level.

\section{Cortisol measurement}

Serum samples were obtained by venous blood collected in the morning, before breakfast, in red topped tubes. The samples were allowed to clot for $2 \mathrm{~h}$ at room temperature before centrifugation for $20 \mathrm{~min}$ at $1000 \mathrm{rpm}$. The supernatant was collected and stored at $-20^{\circ} \mathrm{C}$ before testing.

The cortisol level was evaluated using a competitive inhibition enzyme immunoassay technique: cortisol ELISA Kit (Cusabio Biotech Co., Ltd.) following the manufacturer instructions.

The concentration of cortisol in the serum samples was evaluated with the use of eight standard solutions with well know cortisol concentrations in order to generate a standard curve. From the standard stock solution (S7) (200 $\mathrm{ng} / \mathrm{mL})$ standard dilutions were prepared: $56(50 \mathrm{ng} / \mathrm{mL})$, S5 $(12.5 \mathrm{ng} / \mathrm{mL}), \mathrm{S} 4(3.12 \mathrm{ng} / \mathrm{mL}), \mathrm{S} 3(0.78 \mathrm{ng} / \mathrm{mL}), \mathrm{S} 2$ $(0.195 \mathrm{ng} / \mathrm{mL})$, S1 $(0.049 \mathrm{ng} / \mathrm{mL})$, S0 $(0 \mathrm{ng} / \mathrm{mL})$.

This technique used 96 well plate pre-coated with the antigen (cortisol), antibodies specific for cortisol, horseradish peroxidase (HRP) conjugated goat anti-rabbit antibodies and a specific substrate for the enzyme (3,3'5,5'-Tetramethylbenzidine - TMB). This substrate develops a blue colour with different intensity in function of the amount of cortisol in the serum samples. The optical density (OD value) of each well was determined using a microplate reader (Stat Fax 3200 Awareness Technology Inc.) set to $450 \mathrm{~nm}$.

The OD of the serum sample were compared to the OD of the standard curve generated (Fig. 1). In competition assay the greater the amount of antigen (cortisol) in the sample, the lower the colour development and optical density reading.

\section{Data analysis}

The conversion of the average OD values in $\mathrm{ng} / \mathrm{mL}$ was accomplished using a formula according to the Excel. Then data was statistically analysed by using Student's t-test
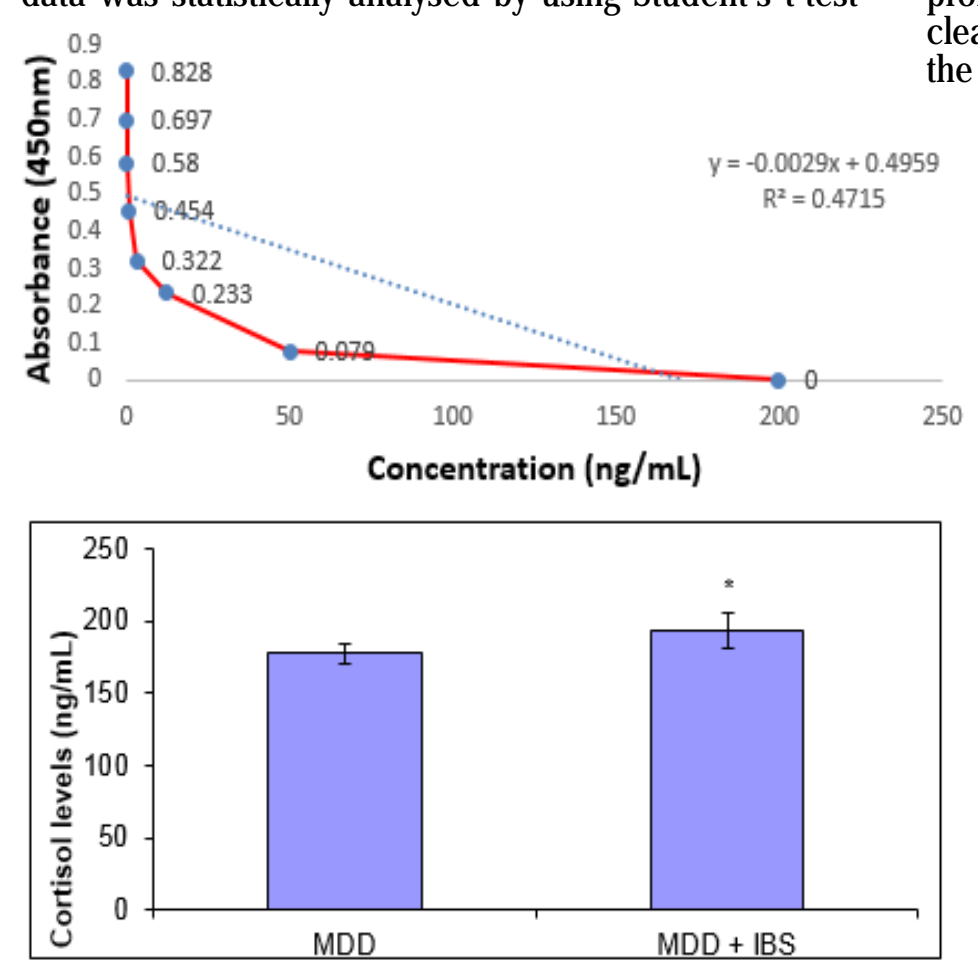

(two tailed, unpaired). All results are expressed as mean \pm SE. $p<0.05$ was regarded as statistically significant. The analyses were performed using the Excel program.

\section{Results and discussion}

As previously mentioned [27], from the 12 patients which were included in the study, 4 patients had major depression and irritable bow el syndrome, while the other 8 patients had depression without irritable bowel syndrome. The age of the patients varied between 43 and 60 years old. The mean age of the study group was 43 $( \pm 5.77)$ years and the mean age for the control group was $55.2( \pm 4.8$ ) years. Our group included both male and female and they were from both urban and rural background.

The mean age for HAMD score was $29.33( \pm 1.15)$ for the study group and $30( \pm 2.64)$ for the control group.

As it can be seen in the figure 2, cortisol levels, as expressed in $\mathrm{ng} / \mathrm{mL}$, were significantly $(p<0.05)$ increased in the major depression disorder + IBS, as compared with those having major depression disorder alone (the so-called control group) (Fig. 2).

Thus, our data presented here are suggesting that there is a significant increase in cortisol levels in the morning serum of the patients with major depression disorder + IBS, as compared to the control group having only major depression disorder.

Regarding the previous studies in this area of research, it was for example showed that there are increased levels of cortisol in the morning (with decreased levels in the evening) in the saliva of 55 patients with IBS, as compared to 28 controls [17]. However, this data was not sustained by any additional modification in the physiological and psychiatric profile of the patients, as determined by a complex set of self-administered questionnaires such as: the Rome Burnout Inventory (RBI) in its physical (RBI-PE) and emotional-mental exhaustion (RBI-EME) components, Beck Depression Inventory, State and Trait Anxiety Inventory (STAI), Perceived Social Support Scale (PSSS) and a Scale for the Assessment of Perceived Actual WorkNon Work Stress [17].

On the other side, on the Sugaya study from 2015 [16], where 10 female student college with IBS had a 2 weeks prolonged stressful teaching kindergarten practice, the clear increase in cortisol levels were obtained only during the first week of the practice and were not that clear for

Fig. 1. Cortisol standard curve

Fig. 2. Cortisol levels $(\mathrm{ng} / \mathrm{mL})$ in patients with major depression disorder (MDD), as compared with those with major depression disorder and irritable bowel syndrome (IBS). $* p<0.05$ vs. MDD alone group 
example in other four different experimental situations such as: before sleep, 30 minutes after waking up, few days after practice or in the second week of this stressful expose [16]. Even more, it seems that no other adrenal hormones suffered any modifications during this exposure to the stressful stimuli (e.g. teaching in kindergarten) [16].

In addition, in a very recent and complex Swedish study in 169 IBS patients, diagnosed using Rome III criteria and selected from 10 different primary health care centres, increased hair cortisol levels were reported [28].

Also it seems that mechanistically speaking inflammation could also play a partin this effects, (together of course with the dysregulations of HPA axis and a negative feedback with it [28], as we will insist immediately), since for example it was previously demonstrated that cortisol and some inflammatory cytokines (e.g. IL 6 and IL 8) were found to be increased together in all 4 subgroups of selected IBS patients (those with diarrhea, constipated, a predominant one or alternators) of 76 patients with IBS, diagnosed with Rome II criteria in 2006 [29].

As previously mentioned, there seem to be an important correlation between oxytocin, HPA axis and cortisol levels for the depressive pathophysiology [14], with oxytocin exerting generally some protective actions (e.g. as some kind of anti-stress molecule), since it can modulate neuroendocrine axes and adjusting the cortisol levels especially under stressful conditions [30]. There are also important correlations to be mentioned here between cortisol levels and the anxiety-related states [31], since our group also showed some protective effects of oxytocin in anxietyrelated behaviour and a variety of associated neuropsychiatric manifestations [32-38].

In addition, we previously showed that there is a significant decrease of serum oxytocin levels in patients with major depression disorder and irritable bowel syndrome, as compared with those having major depression disorder alone [27].

The results presented here could have an important relevance in the context of managing the stress-related factors in the pathological entities described above (e.g. IBS, MDD - combined or separately).

Regarding the limitations of the present report we can mention again the reduced number of patients from both groups, as this was only a preliminary study design in order to understand if there are any serum cortisol levels variations in patients with depression and irritable bowel syndrome, by looking at cortisol modifications in two different groups of patients: a control group with major depression disorder and another study group composed by major depression disorder + IBS patients.

\section{Conclusions}

We preliminary report here a significant increase in the morning serum cortisol of patients with major depression disorder + IBS, as compared to the control group having only major depression disorder.

Acknowledgments: PM and CA are supported by a research great for Young Teams offered by UEFISCDI Romania, no. PN-III-P1-1.1-TE-20161210 , contract no. 58 from 02/05/2018, called Complex study regarding the interactions between oxidative stress, inflammation and neurological manifestations in the pathophysiology of irritable bowel syndrome (animal models and human patients).

\section{References}

1. CASPI, A., SUGDEN, K., MOFFITT, T.E., TAYLOR, A., CRAIG, I.W., HARRINGTON, H., MCCLAY, J., MILL, J., MARTIN, J., BRAITHWAITE, A., POULTON, R., Science, 301, no. 5631, 2003, p. 386, DOI:10.1126/ science.1083968.

2. YANG, L., ZHAO, Y., WANG, Y., LIU, L., ZHANG, X., LI, B., CUI, R., Curr. Neuropharmacol., 13, no. 4, 2015, p. 494, doi:10.2174/ $1570159 \times 1304150831150507$.

3. SHAKOOR SHABAAN, M.A., SHAABAN, I., ALATRAM, A.R., GAD, E.F., AAMJ , 13 , no. 4, Suppl 1, 2015, p. 79.

4. VREEBURG, S.A., HOOGENDIJK, W.J., DERIJK, R.H., VAN DYCK, R., SMIT, J.H., ZITMAN, F.G., PENNINX, B.W., Psychoneuroendocrinology, 38, no. 9, 2013, p. 1494, https://doi.org/10.1016/j.psyneuen.2012.12.017. 5. HOLSBOER, F., Neuropsychopharmacology, 23, 2000, p. 477, DOI:10.1016/S0893-133X(00)00159-7.

6.PLOTSKY, P.M., OWENS, M.J., NEMEROFF, C.B., Psychoneuroendocrinology, 21, 1998, p. 293.

7.DIENES, K.A, HAZEL, N.A., HAMMEN, C.L., Psychoneuroendocrinology, 38, no. 6, 2013, p. 927, DOI:10.1016/j.psyneuen. 2012.09.019.

8. VREEBURG, S.A., HOOGENDIJK, W.J ., VAN PELT, J., DERIJK, R.H., VERHAGEN, J.C., VAN DYCK, R., SMIT, J.H., ZITMAN, F.G., PENNINX, B.W., Arch. Gen. Psychiatry, 66, no. 6, 2009, p. 617, DOI:10.1001/ archgenpsychiatry.2009.50.

9. CARROLL, B.J., CASSIDY, F., NAFTOLOWITZ, D., TATHAM, N.E., WILSON, W.H., IRANMANESH, A., VELDHUIS, J.D., Acta Psychiatr. Scand., 115, 2007, p. 90, DOI:10.1111/j.1600-0447.2007.00967.x.

10.MAES, M., CALABRESE, J., MELTZER, H.Y., Prog. Neuropsychopharmacol. Biol. Psychiatry, 18, 1994, p. 503.

11. PEETERS, F., NICOLSON, N.A., BERKHOF, J., Psychiatry Res., 126, 2004, p. 1, DOI:10.1016/j.psychres.2003.12.010.

12. STRICKLAND, P.L., DEAKIN, J.F.W., PERCIVAL, C., DIXON, J., GATER, R.A., GOLDBERG, D.P., Br. J. Psychiatry, 180, 2002, p. 168, DOI:10.1192/bjp.180.2.168.

13. BHAGWAGAR, Z., HAFIZI, S., COWEN, P.J ., Psychopharmacology, 182, 2005, p. 54, DOI:10.1007/s00213-005-0062-z.

14. CIOBICA, A., BALMUS, I. M., PADURARIU, M., Acta Endocrinologica, 12, no. 1, 2016, p. 65, doi: 10.4183/aeb.2016.65.

15. LEFTER, R., CIOBICA, A., QUEEN, S., COMPAORE, M., TIENDREBEOGO, M., STANCIU, C., TRIFAN, A., Neurophysiology, 50, no. 4, 2018, p. 266.

16. SUGAYA, N., IZAWA, S., SAITO, K., SHIROTSUKI, K., NOMURA, S., SHIMADA, H., Biopsychosoc. Med., 9, no. 1, 2015, p. 4, doi:10.1186/ s13030-015-0031-7.

17. PATACCHIOLI, F.R., ANGELUCCI, L., DELLERBA, G., MONNAZZI, P., LERI, O., J Endocrinol Invest., 24, no. 3, 2001, p. 173.

18. LEFTER, R., CIOBICA, A., TIMOFTE, D., ABABEI, D., DOBRIN, R., LUCA, A. TRIFAN, A., STANCIU, C., SFARTI, C., Romanian Biotechnological Letters, 24, 2019, DOI: 10.26327/RBL2018.208.

19. COJOCARIU, R., CIOBICA, A., BALMUS, I.M., GUENNE, S., TRIFAN, A., STANCIU, C., HRITCU, L., LEFTER, R., Antioxidant Capacity and Behavioral Relevance of a Polyphenolic Extract of Chrysanthellum americanum in a Rat Model of Irritable Bowel Syndrome, Oxidative Medicine and Cellular Longevity, 2019,

20. DINAN, T.G., QUIGLEY, E.M., AHMED, S.M., SCULLY, P., O'BRIEN, S., O'MAHONY, L., SHANAHAN, F., KEELING, P.W., Gastroenterology, 130, 2006, p. 304, DOI:10.1053/j.gastro.2005.11.033.

21. CHANG, L., SUNDARESH, S., ELLIOTT, J., ANTON, P.A., BALDI, P., LICUDINE, A., MAYER, M., VUONG, T., HIRANO, M., NALIBOFF, B.D., AMEEN, V.Z., MAYER, E.A., Neurogastroenterol. Motil., 21, 2009, p. 149, DOI:10.1111/j.1365-2982.2008.01171.x.

22. ERIKSSON, E.M., ANDREN, K.I., ERIKSSON, H.T., KURLBERG, G.K., World J. Gastroenterol., 14, 2008, p. 4889, doi: 10.3748/wjg.14.4889. 23. ELSENBRUCH, S., LOVALLO, W.R., ORR, W.C., Psychosom. Med., 63, 2001, p. 805. 
24. ELSENBRUCH, S., LUCAS, A., HOLTMANN, G., HAAG, S., GERKEN, G., RIEMENSCHNEIDER, N., LANGHORST, J , KAVELAARS, A., HEIJ NEN, C.J., SCHEDLOWSKI, M., Am. J. Gastroenterol., 101, 2006, p. 2300, DOI:10.1111/j.1572-0241.2006.00837.x.

25. POSSERUD, I., AGERFORZ, P., EKMAN, R., BJ ÖRNSSON, E.S., ABRAHAMSSON, H., SIMRÉN, M., Gut., 53, 2004, p. 1102, DOI:10.1136/ gut.2003.017962.

26. SUGAYA, N., IZAWA, S., KIMURA, K., OGAWA, N., YAMADA, C.K., SHIROTSUKI, K., MIKAMI, I., HIRATA, K., NAGANO, Y., NOMURA, S., SHIMADA, H., Int. J. Psychophysiol., 84, 2012, p. 39, DOI:10.1016/ j.ijpsycho.2012.01.006.

27. GAVRIL, R., HRITCU, L., PADURARIU, M., CIOBICA, A., HORHOGEA, C., STEFANESCU, G., SPATARU, M. C., STRAULEA, C., STEFANESCU, C., Rev. Chim. (Bucharest), 70, no. 6, 2019, p. 2204

28. NORLIN, A.K., WALTER, S., THEODORSSON, E., TEGELSTROM, V., GRODZINSKY, E., JONES, M.P., FARESJ O, A., J. Psychosom. Res., 93, 2017, p. 69, DOI:10.1016/j.jpsychores.2016.12.009.

29. DINAN, T.G., QUIGLEY, E.M., AHMED, S.M., SCULLY, P., O'BRIEN, S., O'MAHONY, L., O'MAHONY, S., SHANAHAN, F., KEELING, P.W., Gastroenterology, 130, no. 2, 2006, p. 304, DOI:10.1053/ j.gastro.2005.11.033.

30. TURNER, R.A., ALTEMUS, M., ENOS, T., COOPER, B., MCGUINNESS, T., Psychiatry, 62, no. 2, 1999, p. 97.
31. LENZE, E.J ., MANTELLA, R.C., SHI, P., GOATE, A. M., NOWOTNY, P., BUTTERS, M. A., ANDREESCU, C., THOMPSON, P. A., ROLLMAN, B. L., Am. J. Geriatr. Psychiatry., 19, no. 5, 2011, p. 482, doi:10.1097/ JGP.0b013e3181ec806c.

32. PADURARIU, M., PREPELITA, R., CIOBICA, A., DOBRIN, R., TIMOFTE, D., STEFANESCU, C., CHIRITA, R., The concept of suicide: neurophysiological/genetic theories and possible oxytocin relevance, Neurophysiology, 48, no 4, 2016, p. 312, DOI 10.1007/s11062-016-96039

33. PADURARIU, M., CIOBICA, A., Nobel Medicus, 13, no. 3, 2017, p. 5 34. PADURARIU, M., ANTIOCH, I., CIOBICA, A., LEFTER, R., SIMION, L., Rev. Chim (Bucharest), 68, no. 8, 2017, p. 1879.

35. ANTIOCH, I., ABABEI, D., LEFTER, R., CIOBICA, A., HONCERIU, C., BILD, V., Rev. Chim (Bucharest), 68, no. 9, 2017, p. 2028.

36. BALMUS, I.M., LEFTER, R., CIOBICA, A., ANTIOCH, I., ABABEI, D., DOBRIN, R., Psychiatr. Danub., 30, no. 1, 2018, p. 91, DOI:10.24869/ psyd.2018.91.

37. PADURARIU, M., BALMUS, M., CIOBICA, A., LEFTER, R., COJOCARU, S., ANTIOCH, I., H., DOBRIN, R., ABABEI, D. C., BILD, V., Farmacia, 66, no. 3, 2018, p. 421.

38. BALMUS, I.M., CIOBICA, A., STOICA, B., LEFTER, R., COJOCARU, S.I., REZNIKOV, A., Neurophysiology, 51, no. 1, 2019, p. 18, DOI 10.1007/ s11062-019-09785-w.

$\overline{\text { Manuscript received: } 26.04 .2019}$ 